\title{
MANAGEMENT OF ENDOCRINE DISEASE Novel anabolic treatments for osteoporosis
}

\section{Ernesto Canalis}

Departments of Orthopaedic Surgery and Medicine, UConn Musculoskeletal Institute, UConn Health, Farmington, Connecticut, USA

\begin{abstract}
Skeletal anabolic agents enhance bone formation, which is determined by the number and function of osteoblasts. Signals that influence the differentiation and function of cells of the osteoblast lineage play a role in the mechanism of action of anabolic agents in the skeleton. Wnts induce the differentiation of mesenchymal stem cells toward osteoblasts, and insulin-like growth factor I (IGF-I) enhances the function of mature osteoblasts. The activity of Wnt and IGF-I is controlled by proteins that bind to the growth factor or to its receptors. Sclerostin is a Wnt antagonist that binds to Wnt co-receptors and prevents Wnt signal activation. Teriparatide, a 1-34 amino terminal fragment of parathyroid hormone (PTH), and abaloparatide, a modified 1-34 amino terminal fragment of PTH-related peptide (PTHrp), induce IGF-I, increase bone mineral density (BMD), reduce the incidence of vertebral and non-vertebral fractures and are approved for the treatment of postmenopausal osteoporosis. Romosozumab, a humanized antisclerostin antibody, increases bone formation, decreases bone resorption, increases BMD and reduces the incidence of vertebral fractures. An increased incidence of cardiovascular events has been associated with romosozumab, which is yet to be approved for the treatment of osteoporosis. In conclusion, cell and molecular studies have formed the foundation for the development of new anabolic therapies for osteoporosis with proven efficacy on the incidence of new fractures.
\end{abstract}

\section{Introduction}

Osteoporosis is a disease characterized by low bone mass, increased bone porosity and microarchitectural deterioration of the skeleton causing bone fragility and a predisposition to fractures. Osteoporosis is a major health problem, and it is considered that over 200 million individuals suffer from the disease and an estimated 9

\section{Invited Author's profile}

Dr Ernesto Canalis is a Professor in the Departments of Orthopedic Surgery and Medicine at the University of Connecticut Health Center, Farmington, Connecticut, USA. The Canalis' laboratory discovered the existence of skeletal growth factors and his interests center around growth factors and their antagonists, anabolic agents and determinants of cell fate, such as Notch.

(C) 2018 European Society of Endocrinology Printed in Great Britain million new osteoporotic fractures occur in a given year $(1,2)$. Consequently, treatments for osteoporosis are evaluated by their effectiveness in reducing the incidence of new fractures. Following the menopause, bone remodeling is increased and bone resorption exceeds the capacity of the skeleton to form new bone. As a result, 
there is a loss of cancellous and cortical bone. By targeting the generation, function and survival of bone resorbing osteoclasts, anti-resorptive therapy prevents the loss of skeletal structure and stabilizes the skeleton but fails to restore bone mass and architecture. Therefore, there has been a continued interest in the development of agents capable of increasing bone mass with the hope to restore skeletal architecture.

To have a better understanding of anabolic agents, this review addresses cellular events responsible for bone remodeling, signals and pathways known to enhance bone formation as well as current and newly developed anabolic therapies for osteoporosis.

\section{Skeletal cells and bone remodeling}

Bone remodeling is a highly regulated process that results in bone resorption coupled to the formation of skeletal tissue. Bone remodeling occurs in basic multicellular units, where osteoclasts resorb bone; and following a reversal period, osteoblasts fill the cavity with a collagenous matrix, which is then mineralized (3). Osteoclasts are multinucleated cells derived from the myeloid lineage, and osteoblasts are mononuclear cells derived from mesenchymal cells (4). Osteoblasts can differentiate into quiescent lining cells and into osteocytes, terminally differentiated osteoblasts that are embedded in the mineralized matrix. Osteocytes form a canalicular network to communicate their signals to osteoblasts and osteoclasts. As a consequence, osteocytes play a major role in skeletal remodeling. Osteocytes secrete receptor activator of nuclear factor kappa B ligand (RANKL); and through this mechanism, they control osteoclastogenesis and bone resorption. Osteocytes are a source of sclerostin, a Wnt antagonist, and through this mechanism, they control osteoblastogenesis and bone formation (5). Signals that determine the replication, differentiation, function and death of cells of the osteoblast and osteoclast lineages dictate bone remodeling. This is a process necessary for the maintenance of calcium homeostasis and the removal of bone preventing the accumulation of aged or weakened bone. In the postmenopausal years, estrogen deficiency leads to excessive bone resorption and bone loss, and a way to control the bone loss is to target cells of the osteoclast lineage and reduce bone resorption. Alternatively, in severe osteoporosis, bone formation can be enhanced by the use of an anabolic agent that can increase the number or the function of osteoblasts. An increase in osteoblast cell number can be obtained by an increase in the replication or differentiation of pre-osteoblastic cells or by a decrease in the death of mature cells. An increase in the function of mature osteoblasts can be obtained by direct effects on the differentiated cells.

\section{Signals controlling osteoblast differentiation and function and mechanisms of anabolic therapies in bone}

The osteoblast cell pool is increased by growth factors with mitogenic activity for cells of the osteoblast lineage; however, whether or not the replicating cells differentiate into mature osteoblasts will determine an anabolic response. Factors that induce the differentiation of cells of the osteoblastic lineage into mature cells or factors that enhance the differentiated function of the osteoblast are necessary to achieve a bone-forming response $(6,7)$. Bone morphogenetic proteins (BMPs) and Wnts induce the differentiation of mesenchymal cells toward mature osteoblasts, whereas insulin-like growth factor (IGF)-I has a lesser effect on cell differentiation but enhances the differentiated function of the osteoblast $(8,9,10,11,12)$. The activities of Wnt, BMPs and IGF-I are regulated at the level of their synthesis and receptor binding, as well as by specific extracellular and intracellular regulatory proteins that control their activity. Some act as carrier proteins, like IGF-I-binding proteins, others act as BMP or Wnt antagonists such as noggin and sclerostin $(8,11,12)$. Approaches to obtain an anabolic response are diverse and include the enhancement of the synthesis or activity of a growth regulator or the targeting of a secreted growth factor antagonist $(10,13,14)$. Intracellular proteins can potentiate or attenuate an anabolic signal but are difficult to target since this would require crossing the cell membrane and reaching inside the cell. Therefore, the development of agents targeting non-secreted proteins is not practical.

\section{Wnt signaling and skeletal homeostasis}

Wnts constitute a family of secreted glycoproteins that play a fundamental role in the biology of many cells. Wnt/ $\beta$-catenin signaling controls skeletal development and adult skeletal homeostasis $(11,15,16)$. In the absence of Wnt, axin, adenomatous polyposis coli and $\beta$-catenin form a complex, leading to the phosphorylation of $\beta$-catenin by casein kinase $1 \alpha$ and glycogen-synthase kinase $3 \beta$ (GSK3 $\beta$ ) (17). Phosphorylated $\beta$-catenin is degraded by ubiquitination (17). Following the binding 
of Wnt to specific frizzled receptors and to the low-density lipoprotein receptor-related protein (LRP) co-receptors 5 and 6, GSK-3 $\beta$ activity is inhibited and $\beta$-catenin is stabilized. $\beta$-catenin translocates to the nucleus where it associates with T-cell-specific transcription factor 4 or to lymphoid enhancer-binding factor 1 to regulate the transcription of target genes required for osteoblastogenesis $(18,19,20,21,22,23,24,25)$.

By inducing Runx-2 and osterix, which are required for osteoblastogenesis, Wnt can enhance bone formation $(26,27)$. In addition, Wnt suppresses adipogenesis (20). Wnt has a less recognized but important inhibitory role in osteoclastogenesis and bone resorption, and the constitutive activation of $\beta$-catenin in cells of the osteoblast or osteoclast lineage causes osteopetrosis $(22,28)$. The mechanism is a direct effect on cells of the osteoclast lineage and an indirect effect secondary to the induction of osteoprotegerin. The downregulation of $\beta$-catenin in osteocytes/osteoblasts and osteoclast precursors causes osteopenia due to a decrease in osteoprotegerin expression and a direct affect in osteoclast progenitors both resulting in an increase in osteoclast number and bone resorption $(15,16,22,24,29)$.

\section{Wnt antagonists}

Wnt activity is modulated by secreted proteins that interact with Wnt or with its receptors to control the activity of Wnt. Wnt antagonists interacting with Wnt are Wnt inhibitory factor (WIF)1, secreted Frizzled-related proteins (sFRP) and Cerberus (11, 14, 30). Antagonists interacting with the Wnt co-receptors LRP5/6 are sclerostin, Dickkopf1 and Wnt modulator in surface ectoderm (WISE) also termed ectodin or sclerostin domain-containing $1(11,14,30)$.

Sclerostin, the product of the Sost gene, is preferentially expressed by osteocytes and binds to the Wnt co-receptor LRP5/6, inhibiting Wnt signaling $(31,32,33)$. As a consequence, sclerostin inhibits osteoblastogenesis and bone formation and enhances osteoclastogenesis and causes bone loss $(34,35)$. Conversely, the inactivation of Sost causes an increase in osteoblast number, bone formation and cortical and trabecular bone with enhanced biomechanical properties (36).

By downregulating the Wnt antagonist sclerostin, mechanical loading activates Wnt signaling suggesting that this mechanism is responsible for coupling mechanical forces to an anabolic response in the skeleton $(37,38,39,40)$. Conversely, sclerostin is upregulated in the unloaded skeleton causing enhanced bone resorption and decreased formation, a mechanism playing a role in disuse osteoporosis (39). Parathyroid hormone (PTH) downregulates sclerostin expression, a mechanism proposed to contribute to the anabolic actions of PTH in the skeleton $(41,42,43)$. It is important to note that serum levels of sclerostin do not correlate with changes in bone mineral density (BMD) in patients with osteoporosis and are of limited diagnostic value in this disease (44, $45,46)$. This is because sclerostin acts locally in the bone microenvironment and serum levels of sclerostin do not reflect changes in sclerostin expression by the osteocyte (47).

The importance of the Wnt/ $\beta$-catenin canonical signaling pathway is underscored by the skeletal disorders associated with alterations in Wnt signaling. Mutations in the SOST gene resulting in the downregulation of the expression of sclerostin, such as sclerosteosis and van Buchem disease, are characterized by a marked increase in bone mass (34, 48, 49, 50, 51, 52, 53, 54). Similarly, activating and inactivating mutations of the Wnt co-receptors LRP5/6 cause significant skeletal phenotypes. Activating mutations of the Wnt co-receptor LRP5 result in increased bone mass, whereas inactivating mutations of this gene cause bone loss $(21,55,56)$. High bone mass syndrome is secondary to missense mutations of LRP5, resulting in reduced affinity of Dkk1 or sclerostin for the co-receptor and consequent increased Wnt signaling $(57,58,59,60)$. Inactivating mutations of LRP5 cause osteoporosis-pseudoglioma syndrome characterized by severe bone loss and fractures $(23,61)$. These findings, in conjunction with studies on the biology of Wnt signaling and its antagonists, have formed the foundation for the development of therapies targeting Wnt antagonists with the purpose of enhancing Wnt signaling.

\section{Insulin-like growth factor I}

IGF-I is a peptide that acts as a systemic and local regulator of skeletal growth. Circulating IGF-I is synthesized in the liver and is growth hormone (GH)-dependent and mediates the effects of $\mathrm{GH}$ on longitudinal bone growth (12). In bone cells, the synthesis of IGF-I is primarily dependent on PTH, and IGF-I is required to obtain an anabolic response to PTH in bone in vitro and in vivo $(62,63)$. Similarly, PTH-related peptide (PTHrp) increases IGF-I secretion by skeletal cells, and IGF-I mediates the effects of PTHrp on bone formation in vitro $(12,64)$. These observations have demonstrated that IGF-I plays an important role in the mechanism of PTH and PTHrp action in bone. Six IGF-binding proteins control IGF-I transport, 
availability and activity (10). IGF-I signals through a transmembrane tyrosine receptor, which activates the insulin receptor substrates to initiate signaling, through either the phosphatidylinositol-3 kinase (PI-3K)-protein kinase B (PKB/Akt) or the MAP kinase pathway (65, 66). IGF-I enhances the differentiated function of the osteoblast and prevents osteoblast apoptosis. IGF-I can regulate osteoblast differentiation indirectly by stabilizing $\beta$-catenin and enhancing Wnt signaling (67). IGF-I is necessary for skeletal development and the maintenance of bone mass. Overexpression of IGF-I in osteoblasts enhances bone formation and increases cancellous bone volume documenting its anabolic effect (68). IGF-I also increases the synthesis of RANKL by the osteoblast; and as a consequence, it can enhance osteoclastogenesis, bone resorption and bone remodeling $(69,70)$. Circulating IGF-I contributes to cortical bone integrity, whereas locally produced skeletal IGF-I plays a more significant role in the maintenance of cancellous bone integrity $(68,71,72)$. Targeted deletions of the IGF-1 receptor in osteoblasts or deletion of elements of the IGF-I signaling pathway cause impaired bone formation and osteopenia confirming that IGF-I is a critical factor in the control of bone formation and remodeling $(72,73)$.

GH and IGF-I play an important role in the acquisition of bone mass during adolescence and in the maintenance of skeletal architecture during adult life (12). A decline in GH and IGF-I secretion and in the cortical bone content of IGF-I occur during aging and may contribule to a role in the pathogenesis of osteoporosis in the elderly. There is a correlation between serum IGF-I levels and BMD in postmenopausal women (74). Human studies to define the effects of GH or IGF-I on bone turnover are limited. At high doses, IGF-I increases bone remodeling, whereas at low doses, it increases bone formation without an effect on bone resorption (75). These observations would suggest that at low doses IGF-I can increase osteoblast function without a deleterious bone resorptive effect. Indeed, experience in subjects with anorexia nervosa associated with osteopenia and decreased serum levels of IGF-I would suggest that this is the case. Administration of IGF-I at doses that normalize serum IGF-I, in combination with estrogen replacement therapy, increases BMD in osteopenic subjects with anorexia nervosa $(76,77)$. GH replacement therapy has beneficial effects on BMD in the GH deficient state, but there is no evidence for skeletal benefit in other clinical conditions $(78,79)$. In postmenopausal osteoporotic subjects, the effects of GH are inconsistent, and well-designed longitudinal studies to demonstrate fracture risk reduction in this condition have not been reported (80).

\section{Anabolic treatments for osteoporosis}

\section{Teriparatide}

Teriparatide, the 1-34 amino terminal fragment of PTH, was the first anabolic agent to be approved for the treatment of osteoporosis. It is approved in postmenopausal women and in men who are at high risk for fracture, such as $T$-score on dual-energy $\mathrm{x}$-ray absorptiometry that is very low, in the context or not of other significant risk factors for fractures such as a previous fragility fracture. Teriparatide is also approved for the treatment of glucocorticoidinduced osteoporosis (81).

The intermittent administration of PTH induces an anabolic response in the skeleton. PTH signals through the PTH 1 receptor, a G protein-coupled protein, which mediates most of the functions of PTH and of PTHrelated peptide (PTHrP). PTH has mitogenic properties for cells of the osteoblast lineage and decreases osteoblast apoptosis (82). As a consequence, the number of boneforming cells is increased. The anabolic actions of PTH are secondary to its direct effects on cells of the osteoblast lineage and indirect effects through the induction of IGF-I and the suppression of sclerostin with the consequent enhancement of Wnt signaling (83). PTH also suppresses Notch signaling, an inhibitor of osteoblast differentiation, in cells of the osteoblast lineage in vitro and in vivo (84). Through these mechanisms, PTH could enhance osteoblastogenesis and increase the osteoblast cell pool. It is unclear why intermittent, low-dose PTH administration is anabolic, whereas sustained PTH increases bone resorption. Although the induction of IGF-I could account for both effects, the anabolic effect of PTH appears to be limited to cancellous bone and not observed in cortical bone and also is congruent with the effects of locally synthesized IGF-I $(85,86)$.

The effects of teriparatide on the treatment of osteoporosis has been studied in postmenopausal women and in men, as well as in subjects with glucocorticoidinduced osteoporosis $(81,87)$. Teriparatide administered at a dose of $20 \mu \mathrm{g}$ daily subcutaneously increases vertebral and femoral BMD over a 21-month period and causes a $65 \%$ reduction in the incidence of vertebral fractures and a $54 \%$ reduction in non-vertebral fractures. The lifeterm exposure to teriparatide is limited to 2 years. The 
relatively short duration of the treatment is because of safety concerns.

Adverse events with teriparatide include mild hypercalcemia, which has been reported in $1-3 \%$ of patients treated $(87,88)$. The Fischer 344 rat exposed to prolonged, high-dose teriparatide develops osteosarcoma $(89,90)$. However, it is not known whether teriparatide increases the risk of osteosarcoma in humans (91). Because of this potential risk, teriparatide is contraindicated in children and in persons at risk of developing osteosarcoma including those with active Paget's disease of bone, unexplained elevations in serum levels of alkaline phosphatase, open epiphyses, prior external beam or implant radiation to the skeleton, skeletal metastases or skeletal malignancies or hereditary disorders predisposing to osteosarcoma.

Discontinuation of teriparatide leads to a rapid decline in BMD (92). Consequently, it is prudent to administer an anti-resorptive agent after the completion of the treatment with teriparatide so that gains in BMD are sustained. Patients who are candidates for anabolic therapy with teriparatide are frequently treated previously with anti-resorptive agents and those with significant inhibitory activity on bone turnover temper the response to teriparatide on BMD $(93,94,95)$. Because of these reasons, it is preferable to administer teriparatide prior to anti-resorptive therapy, although often teriparatide is prescribed following the failure to achieve an optimal therapeutic response with an anti-resorptive agent.

Studies on the simultaneous administration of alendronate and teriparatide or PTH 1-84 have not shown an obvious benefit of combining the two drugs as compared with the administration of either agent alone $(95,96)$. It is of interest that the simultaneous administration of zoledronic acid and teriparatide did not blunt the effect of teriparatide on lumbar spine BMD at 1 year, and combination therapy resulted in a greater increase in hip BMD than teriparatide alone (97). Concomitant therapy with denosumab and teriparatide for two years resulted in a substantial increase in BMD at the lumbar spine, hip and femoral neck that was greater than the one achieved with either agent alone $(98,99)$. Biochemical markers revealed that the increased bone turnover observed with teriparatide was suppressed by denosumab, and this effect might be mechanistically relevant to the greater response in BMD. In a pre-planned two-year extension study, it was demonstrated that subjects switching from teriparatide to denosumab continue to have an increase in BMD, whereas subjects switching from denosumab to teriparatide experience a decline in BMD at the radius and hip. Subjects receiving teriparatide and denosumab for two years continued to gain BMD (100). These observations indicate that it is preferable not to administer teriparatide following potent anti-resorptive therapy, since it may result in a rapid decline in BMD.

\section{Abaloparatide}

Abaloparatide is a synthetic agonist of the PTH type I receptor that was recently approved for the treatment of postmenopausal women with osteoporosis at high risk for fracture. Abaloparatide is a synthetic 34 amino acid peptide and an analog of PTHrp 1-34 with which it shares $76 \%$ homology. Abaloparatide also shares $41 \%$ homology with PTH 1-34. Initial work on the actions of PTHrp demonstrated that when administered intermittently PTHrp has anabolic effects in bone analogous to those observed with PTH. PTHrp causes a dose-dependent increase in biochemical markers of bone formation, such as serum osteocalcin and procollagen 1 aminoterminal propeptide (P1NP) in humans with little effect on biochemical markers of bone resorption (101). Transient exposure of bones to PTHrp in vitro causes an increase in collagen and non-collagen protein synthesis as well as an increase in IGF-I levels. An IGF-I neutralizing antibody prevented the stimulatory effect of PTHrp on bone collagen synthesis, suggesting that the stimulatory effect of PTHrp on bone matrix synthesis is mediated at least in part by an enhancement in the local production of IGF-I (64). These effects are similar to those observed with PTH. Although abaloparatide and teriparatide bind to the PTH type I receptor, abaloparatide binds more efficiently to the RG over the RO conformation of the PTH receptor, and this may lead to a more transient effect of PTHrp and favorable anabolic action (102). Clinical studies have demonstrated a lesser effect of abaloparatide than teriparatide on biochemical markers of bone remodeling (103). This may suggest a tempered effect on bone resorption which might prove to be an advantage over teriparatide.

Treatment with abaloparatide increases BMD at the lumbar spine, femoral neck and total hip in a dosedependent fashion $(103,104)$. The increase in BMD at the total hip is greater with abaloparatide at $80 \mu \mathrm{g}$ daily, the recommended dose, than with teriparatide at $20 \mu \mathrm{g}$ daily. Abaloparatide at a dose of $80 \mu \mathrm{g}$ daily for an 18-month period was studied for its effects on fracture prevention in postmenopausal women with osteoporosis and compared to the effects of placebo and of open-label teriparatide at a dose of $20 \mu \mathrm{g}$ daily. At baseline, $24 \%$ of patients had at least one vertebral fracture and $48 \%$ had at least one 
prior non-vertebral fracture. The relative risk reduction of new vertebral fractures was $86 \%$ and in non-vertebral fractures was $43 \%$ for abaloparatide (104). Although abaloparatide had a greater effect on BMD than teriparatide, the rate reduction in vertebral and nonvertebral fractures was not significantly different. There was a greater reduction in major osteoporotic fractures, defined as fractures of the wrist, upper arm, hip and clinical fractures of the spine, in abaloparatide than in teriparatide-treated subjects. A post hoc analysis revealed that the effect of abaloparatide on fracture risk reduction is independent of baseline clinical risk factors or fracture probability estimated by FRAX (105). Participants in the abaloparatide and placebo groups of the trial were eligible to enter an extension trial, at the completion of the 18-month intervention, where they received alendronate $70 \mathrm{mg}$ once a week for 24 months starting 1 month following the completion of the parent trial. An interim analysis following 6 months of alendronate treatment revealed an $87 \%$ relative risk reduction in morphometric vertebral fractures in the abaloparatide-alendronatetreated population compared to the placebo-alendronatetreated individuals. The initial results indicate a persistent effect of abaloparatide followed by the administration of alendronate (106).

Although abaloparatide is considered an anabolic agent, bone biopsies obtained following a 12- to 18-month administration of abaloparatide at $80 \mu \mathrm{g}$ daily did not reveal an increase in either mineralizing surface or mineral apposition rate so that bone formation was not increased. In the same study, teriparatide at $20 \mu$ g daily increased mineral apposition rate reflecting increased osteoblast activity (107). The reason for the lack of an effect of abaloparatide on histomorphometric parameters of bone formation is not immediately apparent. Eroded surface was decreased in cancellous bone, but cortical porosity was increased by abaloparatide. The histological appearance of iliac crest bone biopsies from subjects treated with abaloparatide was normal suggesting that the agent is safe from a skeletal point of view. The bone histomorphometric analysis findings in humans are in contrast with those in ovariectomized rats. Treatment of ovariectomized rats with abaloparatide for 12 months increased bone formation on trabecular, endocortical and periosteal surfaces without an increase in osteoclast number or eroded surface. Abaloparatide stimulated periosteal expansion and endocortical bone apposition leading to an increase in cortical bone volume (108). These effects were accompanied by an increase in cortical and trabecular bone mass and strength and improved cortical geometry in ovariectomized rats treated with abaloparatide (108).

Adverse events with abaloparatide are limited to nausea, tachycardia and hypercalcemia in 3\% of subjects. To determine the carcinogenic potential of abaloparatide, Fischer 344 rats were administered daily abaloparatide at $10-50 \mu \mathrm{g} / \mathrm{kg}$ subcutaneously. There was a dose-dependent induction of osteosarcomas in rats treated with abaloparatide, and the effect was of a similar magnitude as the one observed with PTH 1-34 (109). It is not known whether or not abaloparatide causes osteosarcoma in humans, but its use is not recommended in patients at increased risk of osteosarcoma, as described for teriparatide. Because of the potential risk of osteosarcoma, the recommended cumulative use of abaloparatide, like teriparatide, is limited to 2 years during an individual's lifetime.

A transdermal formulation of abaloparatide to be administered via a microneedle patch is under development (110).

\section{Romosozumab}

Genetic disorders characterized by gain- and loss-offunction mutations of Wnt co-receptors and the SOST gene have demonstrated that Wnt signaling is enhanced when the antagonist is downregulated or its association with Wnt co-receptors is decreased. These observations formed the foundation for the development of neutralizing antidickkopf1 and anti-sclerostin antibodies, an approach to enhance Wnt signaling $(111,112)$. The latter were developed further for clinical applications. Romosozumab, a monoclonal humanized antibody to sclerostin, has been evaluated for its efficacy, but is not yet approved by regulatory agencies for the treatment of osteoporosis $(113,114)$. In accordance with the enhancement of bone formation and suppression of bone resorption by Wnt signaling, the administration of romosozumab causes a rapid increase in P1NP followed by a sustained decrease in carboxy terminal collagen crosslinks (CTX). The administration of romosozumab at a dose of $210 \mathrm{mg}$ once a month to postmenopausal women with low BMD results in an increase in BMD at vertebral sites and at the hip one year after the initiation of treatment. The increase in BMD is substantially greater than that achieved with either alendronate $(70 \mathrm{mg}$ weekly) or teriparatide $(20 \mu \mathrm{g}$ daily) (115). Analysis of the lumbar spine and hip by quantitative computed tomography (QCT) of subjects treated with romosozumab demonstrated an increase in trabecular and cortical volumetric BMD at vertebral sites 
and an increase in trabecular volumetric BMD at the hip (116). Finite element analysis revealed greater increases in vertebral and hip strength in romosozumab-treated than in teriparatide-treated subjects (117). The positive effects of romosozumab on bone structure were attributed to a contribution of both cortical and trabecular bone compartments at the spine and hip. Romosozumab has a greater effect on areal and volumetric BMD by QCT at the hip than teriparatide in subjects previously treated with bisphosphonates for $\geq 3$ years (118). Interestingly, there was loss of cortical volumetric hip BMD in teriparatide-, but not in romosozumab-treated subjects and this correlated with a greater increase in hip strength by romosozumab as estimated by Finite element analysis. The differences between the two drugs may be related to the dual anabolic and anti-resorptive action of romosozumab in relationship to an exclusive anabolic effect of teriparatide.

Two phase 3 clinical trials assessed the antifracture efficacy of romosozumab. One trial compared romosozumab $210 \mathrm{mg}$ subcutaneously monthly to placebo for 12 months, with both arms followed by openlabel denosumab $60 \mathrm{mg}$ every 6 months for 12 months. The primary endpoint was incident vertebral fractures at 12 and 24 months in women with postmenopausal osteoporosis as defined by a $T$-score of -2.5 to -3.5 at the total hip or femoral neck. Following the initial 12-month period, romosozumab decreased the incidence of new vertebral fractures and clinical fractures by $73 \%$ and $36 \%$, respectively (119). However, romosozumab did not reduce incident non-vertebral fractures significantly. After 24 months, 12 months after the transition to denosumab, subjects treated with romosozumab-denosumab had a $75 \%$ reduction in the incidence of new vertebral fractures and a non-significant reduction in non-vertebral fractures (119). Romosozumab caused a significant and substantial increase in BMD at 12 months at the lumber spine, hip and femoral neck.

In a second pivotal trial, romosozumab $210 \mathrm{mg}$ monthly administered subcutaneously was compared to alendronate $70 \mathrm{mg}$ weekly for 12 months, and both arms were followed by open-label alendronate $70 \mathrm{mg}$ weekly for 12 months in postmenopausal women with osteoporosis and fractures. Over the 24-month period, there was a $48 \%$ reduction in incident vertebral and a $19 \%$ reduction in non-vertebral fractures in subjects treated with romosozumab-alendronate than in the alendronatealendronate-treated ones (120). The subjects who received romosozumab had greater gains in BMD at the lumbar spine and total hip. There was an early rise in the bone formation marker P1NP in the romosozumab group in both trials followed by a return to baseline at 3 months and a suppression of the bone resorption marker CTX levels within the first month, and these remained suppressed during the 12 months of romosozumab administration.

Adverse events with romosozumab included hypersensitivity and development of anti-romosozumab antibodies although these did not seem to affect the efficacy of the agent $(119,120)$. Rare occurrences of osteonecrosis of the jaw, and a small number of atypical femoral fractures were observed in romosuzamab-treated patients. Although no vascular events were noted when romosozumab was compared to placebo, there was a higher incidence of serious cardiovascular events in the trial comparing romosozumab to alendronate. In the first 12 months, there was a $2.5 \%$ incidence of cardiovascular events in romosozumab-treated subjects and $1.9 \%$ in the alendronate arm. Moreover, there was a 2.65 -fold increase in the incidence of cerebrovascular events in romosozumab-treated subjects. A possible mechanism underlying these events is a role for sclerostin in vascular remodeling and homeostasis. It is not probable that alendronate had a vascular protective effect since in placebo-controlled trials alendronate was not shown to decrease vascular events (121). Although the neutralization of sclerostin continues to be a promising new approach in the management of osteoporosis and the overall number of vascular events found in the trial are small, the vascular signal for romosozumab is a source of concern.

Additional concerns regarding the enhancement of Wnt signaling is its tumorigenic potential $(122,123)$. Somatic mutations of the Wnt signaling pathway leading to the stabilization of $\beta$-catenin are associated with various malignancies. However, the risk of malignancy is minimized by the relatively specific expression of sclerostin by the osteocyte and the short duration of therapy in the skeleton. The Wnt antagonist WIF1 is epigenetically silenced in $75 \%$ of human osteosarcomas, and its inactivation in the mouse predisposes to an early appearance of radiation-induced osteosarcoma (124). However, there is no evidence for a predisposition to malignancies in patients with high bone mass syndrome, sclerosteosis or van Buchem disease suggesting that the absence of sclerostin or of its activity does not lead to an increased risk of malignancy. The carcinogenic potential of romosozumab has been assessed in rats treated with romosozumab at $3 \mathrm{mg} / \mathrm{kg}, 10 \mathrm{mg} / \mathrm{kg}$ and $50 \mathrm{mg} / \mathrm{kg}$ weekly. There was no neoplastic change that could be attributed to romosozumab in rats for up to 98 weeks of treatment, and the overall carcinogenic potential of romosozumab is considered low (125). 


\section{Conclusions}

Advances in our understanding of cellular events and signals contributing to osteoblast differentiation and function coupled with genetic evidence for a role of these signals in human disorders have formed the foundation for new therapies for osteoporosis. At the center of the discoveries has been the demonstration of a fundamental role of Wnt signaling and IGF-I in osteoblast differentiation and function. Preclinical and clinical studies demonstrating that IGF-I expression can be enhanced by PTH and PTHrp and that Wnt signaling can be enhanced by targeting the Wnt antagonist sclerostin have been instrumental in the development of practical ways to achieve an anabolic response in bone. Currently approved anabolic agents for the treatment of osteoporosis include teriparatide and abaloparatide. There is hope for the future approval of additional agents, such as romosozumab, although the potential for vascular complications is a source of concern.

\section{Declaration of interest}

The authors declare that there is no conflict of interest that could be perceived as prejudicing the impartiality of the review reported.

\section{Funding}

This work was supported by Grants AR063049 and AR068160 from the National Institute of Arthritis and Musculoskeletal and Skin Diseases, and Grant DK045227 from the National Institute of Diabetes \& Digestive \& Kidney Diseases.

Acknowledgments

The author thanks Mary Yurczak for secretarial assistance.

\section{References}

1 Cooper C, Campion G \& Melton LJ 3rd. Hip fractures in the elderly: a world-wide projection. Osteoporosis International 19922 285-289. (https://doi.org/10.1007/BF01623184)

2 Johnell O \& Kanis JA. An estimate of the worldwide prevalence and disability associated with osteoporotic fractures. Osteoporosis International 200617 1726-1733. (https://doi.org/10.1007/s00198006-0172-4)

3 Parfitt AM. The bone remodeling compartment: a circulatory function for bone lining cells. Journal of Bone and Mineral Research 200116 1583-1585. (https://doi.org/10.1359/ jbmr.2001.16.9.1583)

4 Canalis E. The fate of circulating osteoblasts. New England Journal of Medicine 2005352 2014-2016. (https://doi.org/10.1056/ NEJMe058080)

5 Dallas SL, Prideaux M \& Bonewald LF. The osteocyte: an endocrine cell .. and more. Endocrine Reviews 201334 658-690. (https://doi. org/10.1210/er.2012-1026)
6 Canalis E. Skeletal growth factors. In Osteoporosis, 3rd edn, pp 529-546. Eds R Marcus, D Feldman, D Nelson \& C Rosen. San Diego: Academic Press, 2007.

7 Canalis E. Update in new anabolic therapies for osteoporosis. Journal of Clinical Endocrinology and Metabolism 201095 1496-1504. (https:// doi.org/10.1210/jc.2009-2677)

8 Canalis E, Economides AN \& Gazzerro E. Bone morphogenetic proteins, their antagonists, and the skeleton. Endocrine Reviews 2003 24 218-235. (https://doi.org/10.1210/er.2002-0023)

9 Krishnan V, Bryant HU \& MacDougald OA. Regulation of bone mass by Wnt signaling. Journal of Clinical Investigation $2006 \mathbf{1 1 6}$ 1202-1209. (https://doi.org/10.1172/JCI28551)

10 Gazzerro E \& Canalis E. Skeletal actions of insulin-like growth factors. Expert Review of Endocrinology and Metabolism 2006 1 47-56. (https://doi.org/10.1586/17446651.1.1.47)

11 Canalis E. Wnt signalling in osteoporosis: mechanisms and novel therapeutic approaches. Nature Reviews Endocrinology 2013 9575-583. (https://doi.org/10.1038/nrendo.2013.154)

12 Giustina A, Mazziotti G \& Canalis E. Growth hormone, insulin-like growth factors, and the skeleton. Endocrine Reviews 200829 535-559. (https://doi.org/10.1210/er.2007-0036)

13 Gazzerro E \& Canalis E. Bone morphogenetic proteins and their antagonists. Reviews in Endocrine and Metabolic Disorders 20067 51-65. (https://doi.org/10.1007/s11154-006-9000-6)

14 Kawano Y \& Kypta R. Secreted antagonists of the Wnt signalling pathway. Journal of Cell Science 2003116 2627-2634. (https://doi. org/10.1242/jcs.00623)

15 Kramer I, Halleux C, Keller H, Pegurri M, Gooi JH, Weber PB, Feng JQ, Bonewald LF \& Kneissel M. Osteocyte Wnt/beta-catenin signaling is required for normal bone homeostasis. Molecular and Cellular Biology 201030 3071-3085. (https://doi.org/10.1128/ MCB.01428-09)

16 Monroe DG, McGee-Lawrence ME, Oursler MJ \& Westendorf JJ. Update on Wnt signaling in bone cell biology and bone disease. Gene 2012492 1-18. (https://doi.org/10.1016/j.gene.2011.10.044)

17 Liu C, Li Y, Semenov M, Han C, Baeg GH, Tan Y, Zhang Z, Lin X $\&$ He X. Control of beta-catenin phosphorylation/degradation by a dual-kinase mechanism. Cell 2002108 837-847. (https://doi. org/10.1016/S0092-8674(02)00685-2)

18 Behrens J, von Kries JP, Kuhl M, Bruhn L, Wedlich D, Grosschedl R \& Birchmeier W. Functional interaction of beta-catenin with the transcription factor LEF-1. Nature 1996382 638-642. (https://doi. org/10.1038/382638a0)

19 van de Wetering M, Cavallo R, Dooijes D, van BM, van EJ, Loureiro J, Ypma A, Hursh D, Jones T, Bejsovec A et al. Armadillo coactivates transcription driven by the product of the Drosophila segment polarity gene dTCF. Cell 199788 789-799. (https://doi.org/10.1016/ S0092-8674(00)81925-X)

20 Bennett CN, Longo KA, Wright WS, Suva LJ, Lane TF, Hankenson KD \& MacDougald OA. Regulation of osteoblastogenesis and bone mass by Wnt10b. PNAS 2005102 3324-3329. (https://doi.org/10.1073/ pnas.0408742102)

21 Boyden LM, Mao J, Belsky J, Mitzner L, Farhi A, Mitnick MA, Wu D, Insogna K \& Lifton RP. High bone density due to a mutation in LDLreceptor-related protein 5. New England Journal of Medicine 2002346 1513-1521. (https://doi.org/10.1056/NEJMoa013444)

22 Glass DA, Bialek P, Ahn JD, Starbuck M, Patel MS, Clevers H, Taketo MM, Long F, McMahon AP, Lang RA et al. Canonical Wnt signaling in differentiated osteoblasts controls osteoclast differentiation. Developmental Cell 20058 751-764. (https://doi. org/10.1016/j.devcel.2005.02.017)

23 Gong Y, Slee RB, Fukai N, Rawadi G, Roman-Roman S, Reginato AM, Wang H, Cundy T, Glorieux FH, Lev D et al. LDL receptor-related protein 5 (LRP5) affects bone accrual and eye development. Cell 2001 107 513-523. (https://doi.org/10.1016/S0092-8674(01)00571-2) 
24 Holmen SL, Zylstra CR, Mukherjee A, Sigler RE, Faugere MC, Bouxsein ML, Deng L, Clemens TL \& Williams BO. Essential role of beta-catenin in postnatal bone acquisition. Journal of Biological Chemistry 2005280 21162-21168. (https://doi.org/10.1074/jbc. M501900200)

25 Day TF, Guo X, Garrett-Beal L \& Yang Y. Wnt/beta-catenin signaling in mesenchymal progenitors controls osteoblast and chondrocyte differentiation during vertebrate skeletogenesis. Developmental Cell 20058 739-750. (https://doi.org/10.1016/j.devcel.2005.03.016)

26 Gaur T, Lengner CJ, Hovhannisyan H, Bhat RA, Bodine PV, Komm BS, Javed A, van Wijnen AJ, Stein JL, Stein GS et al. Canonical WNT signaling promotes osteogenesis by directly stimulating Runx2 gene expression. Journal of Biological Chemistry $2005 \mathbf{2 8 0}$ 33132-33140. (https://doi.org/10.1074/jbc.M500608200)

27 Nakashima K, Zhou X, Kunkel G, Zhang Z, Deng JM, Behringer RR \& de CB. The novel zinc finger-containing transcription factor osterix is required for osteoblast differentiation and bone formation. Cell 2002 108 17-29. (https://doi.org/10.1016/S0092-8674(01)00622-5)

28 Wei W, Zeve D, Suh JM, Wang X, Du Y, Zerwekh JE, Dechow PC, Graff JM \& Wan Y. Biphasic and dosage-dependent regulation of osteoclastogenesis by beta-catenin. Molecular and Cellular Biology 201131 4706-4719. (https://doi.org/10.1128/MCB.05980-11)

29 Otero K, Shinohara M, Zhao H, Cella M, Gilfillan S, Colucci A, Faccio R, Ross FP, Teitelbaum SL, Takayanagi H et al. TREM2 and beta-catenin regulate bone homeostasis by controlling the rate of osteoclastogenesis. Journal of Immunology 2012188 2612-2621. (https://doi.org/10.4049/jimmunol.1102836)

30 Piters E, Boudin E \& Van HW. Wnt signaling: a win for bone. Archives of Biochemistry and Biophysics 2008473 112-116. (https://doi. org/10.1016/j.abb.2008.03.006)

31 Kusu N, Laurikkala J, Imanishi M, Usui H, Konishi M, Miyake A, Thesleff I \& Itoh N. Sclerostin is a novel secreted osteoclast-derived bone morphogenetic protein antagonist with unique ligand specificity. Journal of Biological Chemistry 2003278 24113-24117. (https://doi.org/10.1074/jbc.M301716200)

32 Li X, Zhang Y, Kang H, Liu W, Liu P, Zhang J, Harris SE \& Wu D. Sclerostin binds to LRP5/6 and antagonizes canonical Wnt signaling. Journal of Biological Chemistry 2005280 19883-19887. (https://doi. org/10.1074/jbc.M413274200)

33 van Bezooijen RL, Roelen BA, Visser A, van der Wee-Pals L, de Wilt E, Karperien M, Hamersma H, Papapoulos SE, ten Dijke P \& Lowik CW. Sclerostin is an osteocyte-expressed negative regulator of bone formation, but not a classical BMP antagonist. Journal of Experimental Medicine 2004199 805-814. (https://doi.org/10.1084/jem.20031454)

34 Loots GG, Kneissel M, Keller H, Baptist M, Chang J, Collette NM, Ovcharenko D, Plajzer-Frick I \& Rubin EM. Genomic deletion of a long-range bone enhancer misregulates sclerostin in Van Buchem disease. Genome Research 200515 928-935. (https://doi.org/10.1101/ gr.3437105)

35 Winkler DG, Sutherland MK, Geoghegan JC, Yu C, Hayes T, Skonier JE, Shpektor D, Jonas M, Kovacevich BR, StaehlingHampton $\mathrm{K}$ et al. Osteocyte control of bone formation via sclerostin, a novel BMP antagonist. EMBO Journal 200322 6267-6276. (https:// doi.org/10.1093/emboj/cdg599)

36 Li X, Ominsky MS, Niu QT, Sun N, Daugherty B, D'Agostin D, Kurahara C, Gao Y, Cao J, Gong J et al. Targeted deletion of the sclerostin gene in mice results in increased bone formation and bone strength. Journal of Bone and Mineral Research 200823 860-869. (https://doi.org/10.1359/jbmr.080216)

37 Hens JR, Wilson KM, Dann P, Chen X, Horowitz MC \& Wysolmerski JJ. TOPGAL mice show that the canonical Wnt signaling pathway is active during bone development and growth and is activated by mechanical loading in vitro. Journal of Bone and Mineral Research 200520 1103-1113. (https://doi.org/10.1359/ JBMR.050210)
38 Robinson JA, Chatterjee-Kishore M, Yaworsky PJ, Cullen DM, Zhao W, Li C, Kharode Y, Sauter L, Babij P, Brown EL et al. Wnt/betacatenin signaling is a normal physiological response to mechanical loading in bone. Journal of Biological Chemistry $2006 \mathbf{2 8 1}$ 31720-31728. (https://doi.org/10.1074/jbc.M602308200)

39 Robling AG, Niziolek PJ, Baldridge LA, Condon KW, Allen MR, Alam I, Mantila SM, Gluhak-Heinrich J, Bellido TM, Harris SE et al. Mechanical stimulation of bone in vivo reduces osteocyte expression of Sost/sclerostin. Journal of Biological Chemistry 2008283 5866-5875. (https://doi.org/10.1074/jbc.M705092200)

40 Tu X, Rhee Y, Condon KW, Bivi N, Allen MR, Dwyer D, Stolina M, Turner CH, Robling AG, Plotkin LI et al. Sost downregulation and local Wnt signaling are required for the osteogenic response to mechanical loading. Bone 201250 209-217. (https://doi. org/10.1016/j.bone.2011.10.025)

41 Sawakami K, Robling AG, Ai M, Pitner ND, Liu D, Warden SJ, Li J, Maye P, Rowe DW, Duncan RL et al. The Wnt co-receptor LRP5 is essential for skeletal mechanotransduction but not for the anabolic bone response to parathyroid hormone treatment. Journal of Biological Chemistry 2006281 23698-23711. (https://doi. org/10.1074/jbc.M601000200)

42 Sutherland MK, Geoghegan JC, Yu C, Turcott E, Skonier JE, Winkler DG \& Latham JA. Sclerostin promotes the apoptosis of human osteoblastic cells: a novel regulation of bone formation. Bone 200435 828-835. (https://doi.org/10.1016/j.bone.2004.05.023)

43 Bellido T, Saini V \& Pajevic PD. Effects of PTH on osteocyte function. Bone 201354 250-257. (https://doi.org/10.1016/j. bone.2012.09.016)

44 Ardawi MS, Al-Kadi HA, Rouzi AA \& Qari MH. Determinants of serum sclerostin in healthy pre- and postmenopausal women. Journal of Bone and Mineral Research 201126 2812-2822. (https://doi. org/10.1002/jbmr.479)

45 Lapauw B, Vandewalle S, Taes Y, Goemaere S, Zmierczak H, Collette J \& Kaufman JM. Serum sclerostin levels in men with idiopathic osteoporosis. European Journal of Endocrinology: Oslo 2013168 615-620. (https://doi.org/10.1530/EJE-12-1074)

46 Mirza FS, Padhi ID, Raisz LG \& Lorenzo JA. Serum sclerostin levels negatively correlate with parathyroid hormone levels and free estrogen index in postmenopausal women. Journal of Clinical Endocrinology and Metabolism 201095 1991-1997. (https://doi. org/10.1210/jc.2009-2283)

47 Jastrzebski S, Kalinowski J, Stolina M, Mirza F, Torreggiani E, Kalajzic I, Won HY, Lee SK \& Lorenzo J. Changes in bone sclerostin levels in mice after ovariectomy vary independently of changes in serum sclerostin levels. Journal of Bone and Mineral Research 201328 618-626. (https://doi.org/10.1002/jbmr.1773)

48 Balemans W, Ebeling M, Patel N, Van HE, Olson P, Dioszegi M, Lacza C, Wuyts W, Van Den EJ, Willems P et al. Increased bone density in sclerosteosis is due to the deficiency of a novel secreted protein (SOST). Human Molecular Genetics 200110 537-543. (https:// doi.org/10.1093/hmg/10.5.537)

49 Van HW, Balemans W, Van HE, Dikkers FG, Obee H, Stokroos RJ, Hildering P, Vanhoenacker F, Van CG \& Willems PJ. Van Buchem disease (hyperostosis corticalis generalisata) maps to chromosome 17q12-q21. American Journal of Human Genetics 199862 391-399. (https://doi.org/10.1086/301721)

50 Bhadada SK, Rastogi A, Steenackers E, Boudin E, Arya A, Dhiman V, Bhansali A \& Van HW. Novel SOST gene mutation in a sclerosteosis patient and her parents. Bone 201352 707-710. (https://doi. org/10.1016/j.bone.2012.10.009)

51 Brunkow ME, Gardner JC, Van Ness J, Paeper BW, Kovacevich BR, Proll S, Skonier JE, Zhao L, Sabo PJ, Fu Y et al. Bone dysplasia sclerosteosis results from loss of the SOST gene product, a novel cystine knot-containing protein. American Journal of Human Genetics 200168 577-589. (https://doi.org/10.1086/318811) 
52 Piters E, Culha C, Moester M, Van BR, Adriaensen D, Mueller T, Weidauer S, Jennes K, de FF, Lowik C et al. First missense mutation in the SOST gene causing sclerosteosis by loss of sclerostin function. Human Mutation 201031 E1526-E1543. (https://doi. org/10.1002/humu.21274)

53 Balemans W, Patel N, Ebeling M, Van HE, Wuyts W, Lacza C, Dioszegi M, Dikkers FG, Hildering P, Willems PJ et al. Identification of a $52 \mathrm{~kb}$ deletion downstream of the SOST gene in patients with van Buchem disease. Journal of Medical Genetics 200239 91-97. (https://doi.org/10.1136/jmg.39.2.91)

54 Collette NM, Genetos DC, Economides AN, Xie L, Shahnazari M, Yao W, Lane NE, Harland RM \& Loots GG. Targeted deletion of Sost distal enhancer increases bone formation and bone mass. PNAS 2012 109 14092-14097. (https://doi.org/10.1073/pnas.1207188109)

55 Little RD, Carulli JP, Del Mastro RG, Dupuis J, Osborne M, Folz C, Manning SP, Swain PM, Zhao SC, Eustace B et al. A mutation in the LDL receptor-related protein 5 gene results in the autosomal dominant high-bone-mass trait. American Journal of Human Genetics 200270 11-19. (https://doi.org/10.1086/338450)

56 Ellies DL, Viviano B, McCarthy J, Rey JP, Itasaki N, Saunders S \& Krumlauf R. Bone density ligand, Sclerostin, directly interacts with LRP5 but not LRP5G171V to modulate Wnt activity. Journal of Bone and Mineral Research 200621 1738-1749. (https://doi.org/10.1359/ jbmr.060810)

57 Van WL, Cleiren E, Gram J, Beals RK, Benichou O, Scopelliti D, Key L, Renton T, Bartels C, Gong Y et al. Six novel missense mutations in the LDL receptor-related protein 5 (LRP5) gene in different conditions with an increased bone density. American Journal of Human Genetics 200372 763-771. (https://doi.org/10.1086/368277)

58 Williams BO \& Insogna KL. Where Wnts went: the exploding field of Lrp5 and Lrp6 signaling in bone. Journal of Bone and Mineral Research 200924 171-178. (https://doi.org/10.1359/jbmr.081235)

59 Bhat BM, Allen KM, Liu W, Graham J, Morales A, Anisowicz A, Lam HS, McCauley C, Coleburn V, Cain M et al. Structure-based mutation analysis shows the importance of LRP5 beta-propeller 1 in modulating Dkk1-mediated inhibition of Wnt signaling. Gene 2007 391 103-112. (https://doi.org/10.1016/j.gene.2006.12.014)

60 Semenov MV \& He X. LRP5 mutations linked to high bone mass diseases cause reduced LRP5 binding and inhibition by SOST. Journal of Biological Chemistry 2006281 38276-38284. (https://doi. org/10.1074/jbc.M609509200)

61 Balemans W \& Van HW. The genetics of low-density lipoprotein receptor-related protein 5 in bone: a story of extremes. Endocrinology 2007148 2622-2629. (https://doi.org/10.1210/en.2006-1352)

62 Canalis E, Centrella M, Burch W \& McCarthy TL. Insulin-like growth factor I mediates selective anabolic effects of parathyroid hormone in bone cultures. Journal of Clinical Investigation 198983 60-65. (https:// doi.org/10.1172/JCI113885)

63 Miyakoshi N, Kasukawa Y, Linkhart TA, Baylink DJ \& Mohan S. Evidence that anabolic effects of PTH on bone require IGF-I in growing mice. Endocrinology 2001142 4349-4356. (https://doi. org/10.1210/endo.142.10.8436)

64 Canalis E, McCarthy TL \& Centrella M. Differential effects of continuous and transient treatment with parathyroid hormone related peptide (PTHrp) on bone collagen synthesis. Endocrinology 1990126 1806-1812. (https://doi.org/10.1210/endo-126-4-1806)

65 Adams TE, Epa VC, Garrett TP \& Ward CW. Structure and function of the type 1 insulin-like growth factor receptor. Cellular and Molecular Life Sciences 200057 1050-1093. (https://doi.org/10.1007/ PL00000744)

66 Grey A, Chen Q, Xu X, Callon K \& Cornish J. Parallel phosphatidylinositol-3 kinase and p42/44 mitogen-activated protein kinase signaling pathways subserve the mitogenic and antiapoptotic actions of insulin-like growth factor I in osteoblastic cells. Endocrinology 2003144 4886-4893. (https://doi.org/10.1210/ en.2003-0350)
67 Longo KA, Kennell JA, Ochocinska MJ, Ross SE, Wright WS \& MacDougald OA. Wnt signaling protects 3T3-L1 preadipocytes from apoptosis through induction of insulin-like growth factors. Journal of Biological Chemistry 2002277 38239-38244. (https://doi. org/10.1074/jbc.M206402200)

68 Zhao G, Monier-Faugere MC, Langub MC, Geng Z, Nakayama T, Pike JW, Chernausek SD, Rosen CJ, Donahue LR, Malluche HH et al. Targeted overexpression of insulin-like growth factor I to osteoblasts of transgenic mice: increased trabecular bone volume without increased osteoblast proliferation. Endocrinology 2000141 2674-2682. (https://doi.org/10.1210/endo.141.7.7585)

69 Mochizuki H, Hakeda Y, Wakatsuki N, Usui N, Akashi S, Sato T, Tanaka K \& Kumegawa M. Insulin-like growth factor-I supports formation and activation of osteoclasts. Endocrinology 1992131 1075-1080. (https://doi.org/10.1210/endo.131.3.1505451)

70 Wang Y, Nishida S, Elalieh HZ, Long RK, Halloran BP \& Bikle DD. Role of IGF-I signaling in regulating osteoclastogenesis. Journal of Bone and Mineral Research 200621 1350-1358. (https://doi. org/10.1359/jbmr.060610)

71 Yakar S, Canalis E, Sun H, Mejia W, Kawashima Y, Nasser P, Courtland HW, Williams V, Bouxsein M, Rosen C et al. Serum IGF-1 determines skeletal strength by regulating sub-periosteal expansion and trait interactions. Journal of Bone and Mineral Research $20092 \mathbf{4}$ 1481-1492. (https://doi.org/10.1359/jbmr.090226)

72 Zhang M, Xuan S, Bouxsein ML, von Stechow D, Akeno N, Faugere MC, Malluche H, Zhao G, Rosen CJ, Efstratiadis A et al. Osteoblast-specific knockout of the insulin-like growth factor (IGF) receptor gene reveals an essential role of IGF signaling in bone matrix mineralization. Journal of Biological Chemistry 2002277 44005-44012. (https://doi.org/10.1074/jbc.M208265200)

73 Ogata N, Chikazu D, Kubota N, Terauchi Y, Tobe K, Azuma Y, Ohta T, Kadowaki T, Nakamura K \& Kawaguchi H. Insulin receptor substrate-1 in osteoblast is indispensable for maintaining bone turnover. Journal of Clinical Investigation 2000105 935-943. (https:// doi.org/10.1172/JCI9017)

74 Langlois JA, Rosen CJ, Visser M, Hannan MT, Harris T, Wilson PW $\&$ Kiel DP. Association between insulin-like growth factor I and bone mineral density in older women and men: the Framingham Heart Study. Journal of Clinical Endocrinology and Metabolism 199883 4257-4262. (https://doi.org/10.1210/jcem.83.12.5308)

75 Grinspoon S, Baum H, Lee K, Anderson E, Herzog D \& Klibanski A. Effects of short-term recombinant human insulin-like growth factor I administration on bone turnover in osteopenic women with anorexia nervosa. Journal of Clinical Endocrinology and Metabolism 199681 3864-3870. (https://doi.org/10.1210/ jcem.81.11.8923830)

76 Misra M \& Klibanski A. Anorexia nervosa and osteoporosis. Reviews in Endocrine and Metabolic Disorders 20067 91-99. (https://doi. org/10.1007/s11154-006-9005-1)

77 Grinspoon S, Thomas L, Miller K, Herzog D \& Klibanski A. Effects of recombinant human IGF-I and oral contraceptive administration on bone density in anorexia nervosa. Journal of Clinical Endocrinology and Metabolism 200287 2883-2891. (https://doi.org/10.1210/ jcem.87.6.8574)

78 Mazziotti G, Bianchi A, Bonadonna S, Nuzzo M, Cimino V, Fusco A, De ML \& Giustina A. Increased prevalence of radiological spinal deformities in adult patients with GH deficiency: influence of GH replacement therapy. Journal of Bone and Mineral Research 200621 520-528. (https://doi.org/10.1359/jbmr.060112)

79 Ghiron LJ, Thompson JL, Holloway L, Hintz RL, Butterfield GE, Hoffman AR \& Marcus R. Effects of recombinant insulin-like growth factor-I and growth hormone on bone turnover in elderly women. Journal of Bone and Mineral Research 199510 1844-1852. (https://doi. org/10.1002/jbmr.5650101203)

80 Doga M, Bonadonna S, Gola M, Solerte SB, Amato G, Carella C \& Giustina A. Current guidelines for adult GH replacement. Reviews 
in Endocrine and Metabolic Disorders 20056 63-70. (https://doi. org/10.1007/s11154-005-5226-y)

81 Saag KG, Shane E, Boonen S, Marin F, Donley DW, Taylor KA, Dalsky GP \& Marcus R. Teriparatide or alendronate in glucocorticoidinduced osteoporosis. New England Journal of Medicine 2007357 2028-2039. (https://doi.org/10.1056/NEJMoa071408)

82 Jilka RL, Weinstein RS, Bellido T, Roberson P, Parfitt AM \& Manolagas SC. Increased bone formation by prevention of osteoblast apoptosis with parathyroid hormone. Journal of Clinical Investigation 1999104 439-446. (https://doi.org/10.1172/JCI6610)

83 Jilka RL. Molecular and cellular mechanisms of the anabolic effect of intermittent PTH. Bone 200740 1434-1446. (https://doi. org/10.1016/j.bone.2007.03.017)

84 Zanotti S \& Canalis E. Parathyroid hormone inhibits Notch signaling in osteoblasts and osteocytes. Bone 2017103 159-167. (https://doi. org/10.1016/j.bone.2017.06.027)

85 Dempster DW, Cosman F, Kurland ES, Zhou H, Nieves J, Woelfert L, Shane E, Plavetic K, Muller R, Bilezikian J et al. Effects of daily treatment with parathyroid hormone on bone microarchitecture and turnover in patients with osteoporosis: a paired biopsy study. Journal of Bone and Mineral Research 200116 1846-1853. (https://doi. org/10.1359/jbmr.2001.16.10.1846)

86 Hodsman AB, Kisiel M, Adachi JD, Fraher LJ \& Watson PH. Histomorphometric evidence for increased bone turnover without change in cortical thickness or porosity after 2 years of cyclical hPTH(1-34) therapy in women with severe osteoporosis. Bone 2000 27 311-318. (https://doi.org/10.1016/S8756-3282(00)00316-1)

87 Neer RM, Arnaud CD, Zanchetta JR, Prince R, Gaich GA, Reginster JY, Hodsman AB, Eriksen EF, Ish-Shalom S, Genant HK et al. Effect of parathyroid hormone (1-34) on fractures and bone mineral density in postmenopausal women with osteoporosis. New England Journal of Medicine 2001344 1434-1441. (https://doi.org/10.1056/ NEJM200105103441904)

88 Gold DT, Pantos BS, Masica DN, Misurski DA \& Marcus R. Initial experience with teriparatide in the United States. Current Medical Research and Opinion 200622 703-708. (https://doi.org/10.1185/0300 79906X100159)

89 Jolette J, Wilker CE, Smith SY, Doyle N, Hardisty JF, Metcalfe AJ, Marriott TB, Fox J \& Wells DS. Defining a noncarcinogenic dose of recombinant human parathyroid hormone 1-84 in a 2-year study in Fischer 344 rats. Toxicologic Pathology 200634 929-940. (https://doi. org/10.1080/01926230601072301)

90 Vahle JL, Long GG, Sandusky G, Westmore M, Ma YL \& Sato M. Bone neoplasms in F344 rats given teriparatide [rhPTH(1-34)] are dependent on duration of treatment and dose. Toxicologic Pathology 200432 426-438. (https://doi.org/10.1080/01926230490462138)

91 Harper KD, Krege JH, Marcus R \& Mitlak BH. Osteosarcoma and teriparatide? Journal of Bone and Mineral Research 200722334. (https://doi.org/10.1359/jbmr.061111)

92 Black DM, Bilezikian JP, Ensrud KE, Greenspan SL, Palermo L, Hue T, Lang TF, McGowan JA \& Rosen CJ. One year of alendronate after one year of parathyroid hormone (1-84) for osteoporosis. New England Journal of Medicine 2005353 555-565. (https://doi.org/10.1056/ NEJMoa050336)

93 Ettinger B, San MJ, Crans G \& Pavo I. Differential effects of teriparatide on BMD after treatment with raloxifene or alendronate. Journal of Bone and Mineral Research 200419 745-751. (https://doi. org/10.1359/jbmr.040117)

94 Cosman F, Nieves J, Zion M, Woelfert L, Luckey M \& Lindsay R. Daily and cyclic parathyroid hormone in women receiving alendronate. New England Journal of Medicine 2005353 566-575. (https://doi. org/10.1056/NEJMoa050157)

95 Black DM, Greenspan SL, Ensrud KE, Palermo L, McGowan JA, Lang TF, Garnero P, Bouxsein ML, Bilezikian JP \& Rosen CJ. The effects of parathyroid hormone and alendronate alone or in combination in postmenopausal osteoporosis. New England
Journal of Medicine 2003349 1207-1215. (https://doi.org/10.1056/ NEJMoa031975)

96 Finkelstein JS, Hayes A, Hunzelman JL, Wyland JJ, Lee H \& Neer RM. The effects of parathyroid hormone, alendronate, or both in men with osteoporosis. New England Journal of Medicine 2003349 1216-1226. (https://doi.org/10.1056/NEJMoa035725)

97 Cosman F, Eriksen EF, Recknor C, Miller PD, Guanabens N, Kasperk C, Papanastasiou P, Readie A, Rao H, Gasser JA et al. Effects of intravenous zoledronic acid plus subcutaneous teriparatide [rhPTH(1-34)] in postmenopausal osteoporosis. Journal of Bone and Mineral Research 201126 503-511. (https://doi.org/10.1002/ jbmr.238)

98 Leder BZ, Tsai JN, Uihlein AV, Burnett-Bowie SA, Zhu Y, Foley K, Lee $H$ \& Neer RM. Two years of Denosumab and teriparatide administration in postmenopausal women with osteoporosis (The DATA Extension Study): a randomized controlled trial. Journal of Clinical Endocrinology and Metabolism 201499 1694-1700. (https:// doi.org/10.1210/jc.2013-4440)

99 Tsai JN, Uihlein AV, Lee H, Kumbhani R, Siwila-Sackman E, McKay EA, Burnett-Bowie SA, Neer RM \& Leder BZ. Teriparatide and denosumab, alone or combined, in women with postmenopausal osteoporosis: the DATA study randomised trial. Lancet $2013 \mathbf{3 8 2}$ 50-56. (https://doi.org/10.1016/S0140-6736(13)60856-9)

100 Leder BZ, Tsai JN, Uihlein AV, Wallace PM, Lee H, Neer RM \& Burnett-Bowie SA. Denosumab and teriparatide transitions in postmenopausal osteoporosis (the DATA-Switch study): extension of a randomised controlled trial. Lancet 2015386 1147-1155. (https:// doi.org/10.1016/S0140-6736(15)61120-5)

101 Horwitz MJ, Tedesco MB, Garcia-Ocana A, Sereika SM, Prebehala L, Bisello A, Hollis BW, Gundberg CM \& Stewart AF. Parathyroid hormone-related protein for the treatment of postmenopausal osteoporosis: defining the maximal tolerable dose. Journal of Clinical Endocrinology and Metabolism 201095 1279-1287. (https://doi. org/10.1210/jc.2009-0233)

102 Hattersley G, Dean T, Corbin BA, Bahar H \& Gardella TJ. Binding selectivity of abaloparatide for PTH-Type-1-receptor conformations and effects on downstream signaling. Endocrinology 2016157 141-149. (https://doi.org/10.1210/en.2015-1726)

103 Leder BZ, O’Dea LS, Zanchetta JR, Kumar P, Banks K, McKay K, Lyttle CR \& Hattersley G. Effects of abaloparatide, a human parathyroid hormone-related peptide analog, on bone mineral density in postmenopausal women with osteoporosis. Journal of Clinical Endocrinology and Metabolism 2015100 697-706. (https://doi. org/10.1210/jc.2014-3718)

104 Miller PD, Hattersley G, Riis BJ, Williams GC, Lau E, Russo LA, Alexandersen P, Zerbini CA, Hu MY, Harris AG et al. Effect of abaloparatide vs placebo on new vertebral fractures in postmenopausal women with osteoporosis: a randomized clinical trial. JAMA 2016316 722-733. (https://doi.org/10.1001/ jama.2016.11136)

105 McCloskey EV, Johansson H, Oden A, Harvey NC, Jiang H, Modin S, Fitzpatrick L \& Kanis JA. The effect of abaloparatide-SC on fracture risk is independent of baseline FRAX fracture probability: a post hoc analysis of the ACTIVE study. Journal of Bone and Mineral Research 201732 1625-1631. (https://doi.org/10.1002/jbmr.3163)

106 Cosman F, Miller PD, Williams GC, Hattersley G, Hu MY, Valter I, Fitzpatrick LA, Riis BJ, Christiansen C, Bilezikian JP et al. Eighteen months of treatment with subcutaneous abaloparatide followed by 6 months of treatment with alendronate in postmenopausal women with osteoporosis: results of the ACTIVExtend trial. Mayo Clinic Proceedings 201792 200-210. (https://doi.org/10.1016/j. mayocp.2016.10.009)

107 Moreira CA, Fitzpatrick LA, Wang Y \& Recker RR. Effects of abaloparatide-SC (BA058) on bone histology and histomorphometry: the ACTIVE phase 3 trial. Bone 201797 314-319. (https://doi. org/10.1016/j.bone.2016.11.004) 
108 Varela A, Chouinard L, Lesage E, Smith SY \& Hattersley G. One year of abaloparatide, a selective activator of the PTH1 receptor, increased bone formation and bone mass in osteopenic ovariectomized rats without increasing bone resorption. Journal of Bone and Mineral Research 201732 24-33. (https://doi.org/10.1002/jbmr.3003)

109 Jolette J, Attalla B, Varela A, Long GG, Mellal N, Trimm S, Smith SY, Ominsky MS \& Hattersley G. Comparing the incidence of bone tumors in rats chronically exposed to the selective PTH type 1 receptor agonist abaloparatide or $\mathrm{PTH}(1-34)$. Regulatory Toxicology and Pharmacology 201786 356-365. (https://doi.org/10.1016/j. yrtph.2017.04.001)

110 Shirley M. Abaloparatide: first global approval. Drugs 201777 1363-1368. (https://doi.org/10.1007/s40265-017-0780-7)

111 Li X, Ominsky MS, Warmington KS, Morony S, Gong J, Cao J, Gao Y, Shalhoub V, Tipton B, Haldankar R et al. Sclerostin antibody treatment increases bone formation, bone mass, and bone strength in a rat model of postmenopausal osteoporosis. Journal of Bone and Mineral Research 200924 578-588. (https://doi.org/10.1359/ jbmr.081206)

112 Ominsky MS, Vlasseros F, Jolette J, Smith SY, Stouch B, Doellgast G, Gong J, Gao Y, Cao J, Graham K et al. Two doses of sclerostin antibody in cynomolgus monkeys increases bone formation, bone mineral density, and bone strength. Journal of Bone and Mineral Research 201025 948-959. (https://doi.org/10.1002/jbmr.14)

113 Padhi D, Jang G, Stouch B, Fang L \& Posvar E. Single-dose, placebocontrolled, randomized study of AMG 785, a sclerostin monoclonal antibody. Journal of Bone and Mineral Research 201126 19-26. (https://doi.org/10.1002/jbmr.173)

114 McClung MR, Boonen S, Brown JP, Diez-Perez A, Langdahl B, Reginster JY, Zanchetta JR, Katz L, Maddox J, Yang Y et al. Inhibition of sclerostin with AMG 785 in postmenopausal women with low bone mineral density: phase 2 trial results. Journal of Bone and Mineral Research 201227 (Supplement 1) Available at http://www. asbmr.org/education/AbstractDetail?aid=9fa27a06-d9b5-4429a95f-517048985173.

115 McClung MR, Grauer A, Boonen S, Bolognese MA, Brown JP, DiezPerez A, Langdahl BL, Reginster JY, Zanchetta JR, Wasserman SM et al. Romosozumab in postmenopausal women with low bone mineral density. New England Journal of Medicine 2014370 412-420. (https:// doi.org/10.1056/NEJMoa1305224)

116 Genant HK, Engelke K, Bolognese MA, Mautalen C, Brown JP, Recknor C, Goemaere S, Fuerst T, Yang YC, Grauer A et al. Effects of romosozumab compared with teriparatide on bone density and mass at the spine and hip in postmenopausal women with low bone mass.
Journal of Bone and Mineral Research 201732 181-187. (https://doi. org $/ 10.1002 / \mathrm{jbmr} .2932$ )

117 Keaveny TM, Crittenden DB, Bolognese MA, Genant HK, Engelke K, Oliveri B, Brown JP, Langdahl BL, Yan C, Grauer A et al. Greater gains in spine and hip strength for romosozumab compared with teriparatide in postmenopausal women with low bone mass. Journal of Bone and Mineral Research 201732 1956-1962. (https://doi.org/10.1002/ jbmr.3176)

118 Langdahl BL, Libanati C, Crittenden DB, Bolognese MA, Brown JP, Daizadeh NS, Dokoupilova E, Engelke K, Finkelstein JS, Genant HK et al. Romosozumab (sclerostin monoclonal antibody) versus teriparatide in postmenopausal women with osteoporosis transitioning from oral bisphosphonate therapy: a randomised, open-label, phase 3 trial. Lancet 2017390 1585-1594. (https://doi. org/10.1016/S0140-6736(17)31613-6)

119 Cosman F, Crittenden DB, Adachi JD, Binkley N, Czerwinski E, Ferrari S, Hofbauer LC, Lau E, Lewiecki EM, Miyauchi A et al. Romosozumab treatment in postmenopausal women with osteoporosis. New England Journal of Medicine 2016375 1532-1543. (https://doi.org/10.1056/NEJMoa1607948)

120 Saag KG, Petersen J, Brandi ML, Karaplis AC, Lorentzon M, Thomas T, Maddox J, Fan M, Meisner PD \& Grauer A. Romosozumab or alendronate for fracture prevention in women with osteoporosis. New England Journal of Medicine 2017377 1417-1427. (https://doi. org/10.1056/NEJMoa1708322)

121 Rosen CJ. Romosozumab - promising or practice changing? New England Journal of Medicine 2017377 1479-1480. (https://doi. org/10.1056/NEJMe1711298)

122 Bienz M \& Clevers H. Linking colorectal cancer to Wnt signaling. Cell 2000103 311-320. (https://doi.org/10.1016/S0092-8674(00)00122-7)

123 Clevers H. Wnt/beta-catenin signaling in development and disease. Cell 2006127 469-480. (https://doi.org/10.1016/j.cell.2006.10.018)

124 Kansara M, Tsang M, Kodjabachian L, Sims NA, Trivett MK, Ehrich M, Dobrovic A, Slavin J, Choong PF, Simmons PJ et al. Wnt inhibitory factor 1 is epigenetically silenced in human osteosarcoma, and targeted disruption accelerates osteosarcomagenesis in mice. Journal of Clinical Investigation 2009119 837-851. (https://doi. org/10.1172/JCI37175)

125 Chouinard L, Felx M, Mellal N, Varela A, Mann P, Jolette J, Samadfam R, Smith SY, Locher K, Buntich S et al. Carcinogenicity risk assessment of romosozumab: a review of scientific weightof-evidence and findings in a rat lifetime pharmacology study. Regulatory Toxicology and Pharmacology 201681 212-222. (https://doi. org/10.1016/j.yrtph.2016.08.010)

Received 3 November 2017

Revised version received 7 November 2017

Accepted 7 November 2017 